\title{
PENGARUH SISTEM INFORMASI AKUNTANSI MANAJEMEN, STRATEGI, DAN INOVASI TERHADAP KINERJA OPERASIONAL PERUSAHAAN MANUFAKTUR DALAM MEMASUKI ERA PERDAGANGAN BEBAS
}

\author{
Harry Prabowo \\ Tresno Eka Jaya \\ Universitas negeri Jakarta \\ haharryprabowo@gmail.com
}

\begin{abstract}
Abstrak
Tujuan Penulisan ini adalah untuk menganalisa pengaruh analisis variabel independen terhadap variabel dependen. Penelitian dilakukan dengan menggunakan data primer berupa pernyataan kuesioner tentang variabel independen sistem informasi akuntansi manajemen, strategi, dan inovasi terhadap variabel dependen yaitu kinerja operasional perusahaan. Jumlah sampel yang digunakan yaitu 24 perusahaan manufaktur di DKI Jakarta yang dapat dijangkau oleh peneliti, penentuan sampel ini menggunakan teori Gay. Metode analisis yang digunakan adalah regresi linier berganda dengan uji asumsi klasik yang meliputi uji normalitas, uji multikolonieritas, dan uji heterokedastisitas.

Hasil Penulisan menunjukan bahwa variabel sistem informasi akuntansi manajemen memiliki pengaruh terhadap kinerja operasional perusahaan, strategi memiliki pengaruh terhadap kinerja operasional perusahaan dan inovasi memiliki pengaruh terhadap kinerja operasional perusahaan.
\end{abstract}

Kata Kunci : Sistem Informasi Akuntansi Manajemen, Strategi, Inovasi, Kinerja Operasional Perusahaan.

\section{PENDAHULUAN}

Memasuki era pasar bebas

banyak tantangan dan persaingan

yang harus dihadapi oleh dunia

bisnis, dimana tantangan tersebut

menjadi semakin kompleks. Hal ini

ditandai dengan adanya perubahan

lingkungan dikarenakan kemajuan

Jurnal IImiah Wahana Akuntansi teknologi informasi yang semakin pesat dan menuntut kepekaan pihak perusahaan khususnya dalam hal kinerja untuk merespon perubahan yang akan terjadi, sehingga perusahaan tersebut dapat tetap eksis dalam kancah persaingan. 


\begin{tabular}{|c|c|}
\hline Meningkatnya & dari suatu negara melakukan \\
\hline persaingan dan jumlah pesaing & perdagangan \\
\hline menuntut perusahaan untuk selalu & kemakmuran dari negara tersebut, \\
\hline kebutuhan dan & diindikasikan \\
\hline keinginan konsumen serta berusaha & meningkatnya \\
\hline memenuhi harapan & diantaranya: \\
\hline dengan cara memberikan pelayanan & Domestic Product), (2) meningkatnya \\
\hline yang lebih memuaskan daripada yang & industrialisasi, \\
\hline dilakukan oleh pesaing. Tuntutan & transportasi, \\
\hline perusahaan & pengembangan ke arah globalisasi. \\
\hline persaingan pasar bebas yang semakin & perdagangan \\
\hline dekat dan tuntutan restrukturisasi & internasional tersebut kemudian \\
\hline organisasi agar lebih fleksibel dan & menciptakan \\
\hline adaptif dalam mensikapi berbagai & perekonomian \\
\hline perubahan yang terjadi. Namun hanya & menguntungkan antar negara (pelaku \\
\hline organisasi yang fleksibel dan adaptif & internasional) \\
\hline lah yang mampu bersaing dalam & stabilitas ekonomi di negara tersebut. \\
\hline persaingan & Salah satu bentuk dari perdagangan \\
\hline perdagangan bebas ini. & internasional adalah sistem pasar \\
\hline Perekonomian yang terjadi saat & bebas. \\
\hline ini mengacu pada perekonomian & Saat ini hampir semua negara- \\
\hline terbuka, dimana dalam kondisi ini & negara di dunia menganut sistem pasar \\
\hline setiap negara dapat melakukan & bebas sehingga terhubung satu sama \\
\hline perdagangan antar negara atau & lain. Salah satu penentu meningkat \\
\hline $\begin{array}{l}\text { perdagangan internasional. Tujuan } \\
\text { Jurnal IImiah Wahana Akuntansi }\end{array}$ & menurunya \\
\hline
\end{tabular}


Domestic Product) suatu negara adalah peran serta dari perusahaan manufaktur.

Peran serta perusahaan manufaktur memiliki efek yang cukup besar dalam kondisi ekonomi suatu negara. Adanya perubahan yang terjadi seperti tekanan ekonomi dan pemasaran, tekanan informasi, tekanan lingkungan, harapan karyawan untuk berkembang, struktur dan ukuran organisasi, dan lain sebagainya akan mendorong perusahaan untuk selalu meningkatkan kinerja organisasi dan kinerja karyawan agar dapat bersaing secara global.

Keberhasilan sebuah perusahaan dalam menguasai pangsa pasar sangat bergantung pada baik dan buruknya kinerja dari perusahaan tersebut. Kinerja perusahaan merupakan sesuatu yang dihasilkan oleh suatu perusahaan dalam periode tertentu dengan mengacu pada standar yang ditetapkan. Kinerja Jurnal IImiah Wahana Akuntansi perusahaan merupakan hasil yang dapat diukur dan menggambarkan kondisi empirik suatu perusahaan. Penilaian kinerja terhadap suatu perusahaan merupakan suatu tahap evaluasi kerja yang dapat meningkatkan kualitas pekerjaan bagi kelangsungan aktivitas perusahaan di dalamnya. Pekerjaan yang diinginkan oleh perusahaan terhadap para pekerja memiliki standar mutu (quality) untuk mengukur keberhasilan kerja. Namun kualitas kerja dari beberapa pekerja tidak selamanya sesuai dengan standar mutu yang diberlakukan. Suatu saat situasi dan kondisi tidak memungkinkan untuk mencapai tujuan dan harapan perusahaan tersebut, sehingga menyebabkan penilaian terhadap prestasi kerja yang dihasilkan (performance) menjadi menurun.

Bagi perusahaan go public yang telah tercatat di bursa efek hal ini sangat berguna untuk investor Volume 10, No.2, Tahun 2015 
yang ingin menanamkan modalnya, dengan mengetahui perkembangan perusahaan tersebut. Suatu perusahaan harus mempunyai acuan untuk menilai kinerja perusahaannya tersebut.

Kelangsungan hidup dan pertumbuhan suatu perusahaan tergantung pada sistem informasi akuntansi manajemen (Mulyadi dalam Pamungkas, 2008). Manajemen akan sangat terbantu dengan penggunaan informasi akuntansi yang baik dan akan membantu pihak manajemen dalam pengambilan keputusan yang efektif. Sehingga meminimalisir ketidakpastian dan mengurangi resiko dalam memilih alternatif.

Dalam lingkungan bisnis yang semakin kompetitif, setiap perusahaan dituntut untuk selalu mengembangkan strategi yang dapat menciptakan keunggulan bersaing. Penggunaan strategi yang tepat dapat mengarahkan perusahaan untuk Jurnal IImiah Wahana Akuntansi Volume 10, No.2, Tahun 2015 mampu bersaing dengan kompetitornya.

Selain itu untuk dapat bersaing dengan kompetitornya, perusahaan harus melakukan inovasi, baik dalam proses maupun produk agar dapat terus up to date dengan perkembangan zaman yang semakin maju.

\section{KAJIAN TEORETIK}

\section{Kinerja}

Menurut

Payaman

J.

Simanjuntak $\quad(2005: 3) \quad$ yang mengatakan bahwa kinerja perusahaan adalah agregasi atau akumulasi kinerja semua unit-unit organisasi, yang sama dengan perjumlahan kinerja semua orang atau individu yang bekerja di perusahaan tersebut. Dengan demikian kinerja perusahaan sangat dipengaruhi oleh tiga faktor utama, yaitu dukungan organisasi, kemampuan manajemen, dan kinerja setiap orang yang bekerja di perusahaan tersebut. 
Menurut Wibowo (2007:

102) yang mengatakan bahwa

terdapat tujuh indikator kinerja. Dua

di antaranya mempunyai peran sangat

penting, yaitu tujuan dan motif . Kinerja

ditentukan oleh tujuan yang hendak

dicapai dan untuk melakukannya

diperlukan adanya motif. Tanpa

dorongan motif untuk mencapai tujuan,

kinerja tidak akan berjalan. Dengan

demikian, tujuan dan motif menjadi

indikator utama dari kinerja. Namun,

kinerja memerlukan adanya dukungan

sarana, kompetensi, peluang, standar,

dan umpan balik.

\section{Sistem Informasi Akuntansi}

\section{Manajemen}

Menurut Hansen dan Mowen (2005:4)

sistem informasi akuntansi manajemen

adalah sistem informasi yang

menghasilkan pengeluaran

(output) dengan menggunakan

masukan (input) dan berbagai proses

yang diperlukan untuk memenuhi tujuan tertentu manajemen.

Menurut jurnal Juli

Rahmawati (2011) yang mengatakan

bahwa dimensi sistem informasi akuntansi manajemen terdiri dari empat karakteristik informasi, yaitu; Broad of Scope, Timeliness, Aggregation, Integration.

3. Strategi Menurut Crown Dirgantoro (2004:63) yang mengatakan bahwa strategi merupakan elemen dasar ketiga dari model/kerangka manajemen stratejik yang telah dikemukakan sebelumnya merupakan elemen yang paling akrab dengan para pembuat keputusan ataupun pelaku bisnis, serta merupakan elemen yang paling banyak dikenal dan didengar oleh masyarakat awam, walaupun dengan tingkat pemahaman yang berbeda-beda.

Menurut Crown Dirgantoro (2004:79) manfaat dari penggunaan strategi global akan memperoleh salah satu atau lebih dari empat faktor sebagai berikut; penurunan biaya, 
menaikkan kualitas produk, inovasi internal, sumber inovasi menaikkan preferensi pelanggan, eksternal, implementasi inovasi dan menaikkan kemampuan bersaing. tingkat investasi.

4. InovasiMenurut Fontana dalam

Laurensius Manurung (2010:133) yang mengatakan

Variabel-variabel dalam bahwa inovasi merupakan penelitian ini adalah sistem keberhasilan sosial dan ekonomi informasi akuntansi manajemen berkat ditemukan, diciptakan dan diperkenalkannya cara-cara baru atau kombinasi-kombinasi dari caracara lama dalam mentransformasi input menjadi output sedemikian rupa sehingga menciptakan nilai lebih bagi pengguna (masyarakat).

Menurut Zahra dan Dass (1993) dalam jurnal Yekti Utami yang mengatakan bahwa strategi ini mengungkapkan tujuan organisasi dalam melakukan inovasi, yaitu dengan menjelaskan apa yang akan diinovasi dan bagaimana caranya. Variabel dimensi-dimensi strategi inovasi terdiri dari orientasi kepemimpinan, inovasi proses, inovasi produk, sumber (X1), Strategi (X2), Inovasi (X3), dan Kinerja Operasional Perusahaan (Y). Tempat dalam penelitian ini adalah wilayah DKI Jakarta dengan objek penelitiannya ialah perusahaan manufaktur yang berada di DKI Jakarta. Responden yang menjawab instrumen kuesioner adalah orang yang bekerja di bagian operasional pada perusahaan tersebut, baik manajer maupun staff. Lama penelitian yang penulis lakukan adalah Desember 2014 sampai dengan Januari 2015.

Metode analisis yang digunakan adalah metode kualitatif dengan menggunakan alat uji regresi linier berganda dengan uji asumsi klasik Jurnal IImiah Wahana Akuntansi Volume 10, No.2, Tahun 2015 
yang meliputi uji normalitas, uji

multikolonieritas, dan

heterokedastisitas.
Hasil Penelitian

1. Uji Normalitas

Berikut merupakan hasil One-

Sample Kolmogorov-Smirnov yang

disajikan dalam Tabel 2:

Tabel 2:

Hasil One-Sample Kolmogorov-Smirnov

One-Sample Kolmogorov-Smirnov Test

\begin{tabular}{|c|c|c|}
\hline & & $\begin{array}{c}\text { Unstandardized } \\
\text { Residual }\end{array}$ \\
\hline $\mathrm{N}$ & & 39 \\
\hline Normal & Mean & .0000000 \\
\hline Parameters ${ }^{\mathrm{a}, \mathrm{b}}$ & & \\
\hline & Std. Deviation & 2.25710677 \\
\hline Most Extreme Differences & Absolute & .067 \\
\hline & Positive & .064 \\
\hline & Negative & -.067 \\
\hline Kolmogorov-Smirnov Z & & .420 \\
\hline Asymp. Sig. (2-tailed) & & .995 \\
\hline
\end{tabular}

a. Test distribution is Normal.

b. Calculated from data.

Sumber : Data diolah oleh penulis, 2015

Hasil tabel diatas berguna Kolmogorov-Smirnov adalah sebesar untuk memperjelas data sebaran $0,995>0,05$ maka dapat disimpulkan dalam grafik P-Plot. Besarnya nilai bahwa data berdistribusi normal.

Kolmogorov-Smirnov adalah 0,420 Selain melihat hasil tabel uji

dengan signifikansi sebesar $\quad 0,995$ Kolmogorov-Smirnov (Uji K-S) untuk

Karena nilai menguji apakah variabel-variabel yang 
digunakan dalam penelitian ini terdistribusi normal, normalitas juga dapat dilihat dari grafik P-plots. Dan hasil dari uji normalitas yang ditunjukkan dalam grafik normal $P$-Plot akan lebih memperjelas sebaran data dalam penelitian ini, dimana dasar pengambilan keputusan menurut Ghozali (2011:163) yaitu, jika data menyebar disekitar garis diagonal dan mengikuti arah garis diagonal atau grafik histogramnya menunjukkan pola distribusi normal, maka model regresi memenuhi asumsi normalitas.

Berikut adalah hasil P-Plot Normalitas yang disajikan dalam Gambar 1:

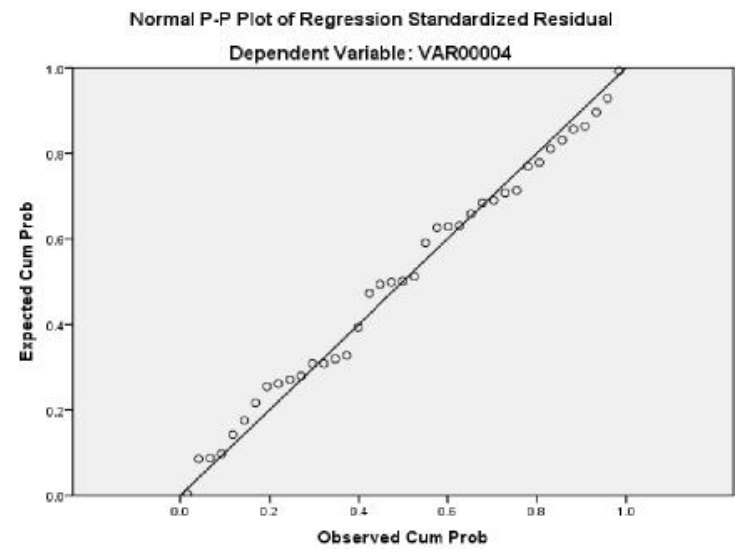

Gambar 1

\section{P-Plot Normalitas}

Berdasarkan dari hasil uji normalitas yang ditunjukkan pada grafik normal P-Plot dapat dilihat titik-titik menyebar di sekitar garis diagonal, serta arah penyebarannya mengikuti arah garis diagonal sehingga dapat disimpulkan bahwa distribusi data normal. Dari hasil uji normalitas yang ditunjukkan pada grafik normal $P$-Plot tersebut menunjukkan bahwa model regresi layak digunakan karena memenuhi asumsi normalitas.

\section{Uji Multikolinearitas}

Berikut hasil pengujian multikolinearitas yang disajikan dalam Tabel 3: 
Tabel 3

Hasil Pengujian Multikolinearitas

Coefficients $^{\mathrm{a}}$

\begin{tabular}{|c|c|c|c|c|c|c|c|}
\hline \multirow[b]{2}{*}{ Model } & \multicolumn{2}{|c|}{$\begin{array}{l}\text { Unstandardized } \\
\text { Coefficients }\end{array}$} & \multirow{2}{*}{$\begin{array}{c}\text { Standardize } \\
\text { d } \\
\text { Coefficient } \\
\text { s } \\
\text { Beta }\end{array}$} & \multirow[b]{2}{*}{$\mathrm{t}$} & \multirow[b]{2}{*}{ Sig. } & \multicolumn{2}{|c|}{$\begin{array}{l}\text { Collinearity } \\
\text { Statistics }\end{array}$} \\
\hline & B & Std. Error & & & & Tolerance & VIF \\
\hline 1 (Constant & -3.728 & 3.816 & & -.977 & .335 & & \\
\hline $\begin{array}{l}\text { SIAM } \\
(\mathrm{X} 1)\end{array}$ & .339 & .149 & .251 & 2.277 & .029 & .483 & 2.072 \\
\hline ST (X2) & .476 & .137 & .452 & 3.469 & .001 & .346 & 2.893 \\
\hline IN (X3) & .313 & .130 & .287 & 2.405 & .022 & .412 & 2.427 \\
\hline
\end{tabular}

a. Dependent Variable: KOP (Y)

Sumber: Data diolah oleh penulis, 2015 Dari hasil uji multikolinearitas yang ditunjukkan pada tabel diatas dapat dilihat bahwa hasil perhitungan nilai Tolerance menunjukkan tidak ada variabel independen yang memliki nilai Tolerance dan VIF pada masingmasing variabel kurang dari 0,10 . Nilai cut off yang umum digunakan untuk mendeteksi adanya multikolinearitas adalah tolerance $>0,10$ atau sama dengan nilai VIF $<10$, dilihat dari tabel diatas menunjukkan bahwa variabel Sistem Informasi Akuntasnsi Manajemen (X1) memiliki nilai VIF 2,072; variabel Strategi (X2) memiliki nilai VIF 2,893; dan variabel Inovasi (X3) memiliki nilai VIF 2,427. Jadi dapat disimpulkan bahwa tidak ada korelasi antar variabel independen dalam model regresi.

\section{Uji Heteroskedastisitas}

Untuk menguji ada atau tidaknya gejala heteroskedastisitas, maka dapat dilihat dari scatterplot pada gambar 2 di bawah ini: 


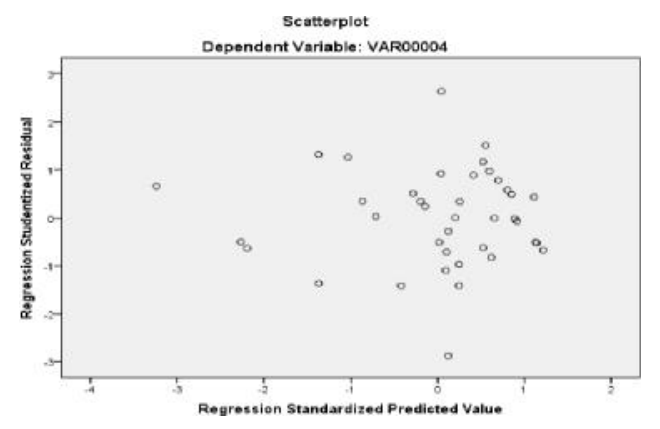

Gambar 2

Scatterplot

Dari hasil uji

heteroskedastisitas yang

ditunjukkan pada gambar

scatterplot diatas, dapat dilihat

bahwa penyebaran data berada

diatas dan dibawah angka nol. Dan

data tidak membentuk suatu pola

tertentu sehingga dapat

disimpulkan bahwa tidak adanya

gejala heteroskedastisitas pada

residual.

Selain itu uji heterokedasitisitas juga

bisa dilihat dari hasil table uji glejser. Uji Glejser ini bertujuan untuk memastikan bahwa tidak terdapat gejala heteroskedastisitas pada model regresi penelitian ini. Untuk menguji ada atau tidaknya gejala heteroskedastisitas dapat dilihat dari probabilitas signifikan. Apabila probabilitas signifikan diatas tingkat kepercayaan 5\%, hal tersebut mengindikasikan bahwa model regresi tidak mengandung adanya Heterokedastisitas. Sedangkan Apabila probabilitas signifikan dibawah tingkat kepercayaan 5\%, hal tersebut mengindikasikan bahwa model regresi mengandung adanya Heterokedastisitas.

Hasil uji gletser disajikan dalam Tabel 4 sebagai berikut: 
Tabel 4

Hasil Uji Glejser

Coefficients $^{\text {a }}$

\begin{tabular}{|c|c|c|c|c|c|c|c|}
\hline \multirow[b]{2}{*}{ Model } & \multicolumn{2}{|c|}{$\begin{array}{l}\text { Unstandardized } \\
\text { Coefficients }\end{array}$} & \multirow{2}{*}{$\begin{array}{c}\text { Standardize } \\
\text { Coefficient } \\
\text { S } \\
\text { Beta }\end{array}$} & \multirow[b]{2}{*}{$\mathrm{t}$} & \multirow[b]{2}{*}{ Sig. } & \multicolumn{2}{|c|}{$\begin{array}{c}\text { Collinearity } \\
\text { Statistics } \\
\end{array}$} \\
\hline & B & Std. Error & & & & Tolerance & VIF \\
\hline $\begin{array}{l}1 \text { (Constant } \\
\text { ) }\end{array}$ & 1.700 & 2.357 & & .721 & .476 & & \\
\hline $\begin{array}{l}\text { SIAM } \\
\text { (X1) }\end{array}$ & .020 & .092 & .053 & .222 & .825 & .483 & $\begin{array}{c}2.07 \\
2\end{array}$ \\
\hline ST (X2) & -.081 & .085 & -.271 & $\begin{array}{r}- \\
.955\end{array}$ & .346 & .346 & $\begin{array}{c}2.89 \\
3\end{array}$ \\
\hline IN (X3) & .051 & .080 & .164 & .631 & .532 & .412 & $\begin{array}{c}2.42 \\
7\end{array}$ \\
\hline
\end{tabular}

a. Dependent Variable: ABS1_Y Sumber :

Data diolah oleh penulis, 2015

Hasil tampilan output SPSS

menunjukkan bahwa tidak ada satupun variabel independen yang signifikan secara statistik mempengaruhi variabel dependen nilai absolut UT (ABSUT1_Y). Hal ini terlihat dari probabilitas signifikansinya diatas tingkat kepercayaan 5\%. Jadi, dapat disimpulkan model regresi tidak mengandung adanya heterokedastisitas.

\section{Analisis Regresi Linear}

\section{Berganda}

Selanjutnya uji yang dilakukan pada penelitian ini yaitu analisis regresi linear berganda. Analisis regresi linear berganda ini dilakukan untuk melihat kemampuan variabel independen dalam menjelaskan variabel dependen. Analisis regresi linear berganda dilakukan dengan SIAM (X1), ST (X2) dan IN (X3) sebagai variabel bebas serta KOP (Y) 
sebagai variabel terikat. Adapun

rumus regresi adalah sebagai

berikut:

$\mathrm{Y}=\mathrm{a}+\mathrm{J} 31 \mathrm{SIAM}+\mathrm{J} 32 \mathrm{ST}+\mathrm{J} 33 \mathrm{IN}+\mathrm{e}$
Uji regresi berganda ini

dapat dilihat berdasarkan tabel 5 .

Berdasarkan hasil analisis regresi

yang telah dilakukan diperoleh hasil

sebagai berikut:

\section{Tabel 5}

\section{Hasil Analisis Regresi Linear Berganda}

\section{Coefficients $^{\mathbf{a}}$}

\begin{tabular}{|c|c|c|c|c|c|c|c|}
\hline \multirow[b]{2}{*}{ Model } & \multicolumn{2}{|c|}{$\begin{array}{c}\text { Unstandardized } \\
\text { Coefficients }\end{array}$} & \multirow{2}{*}{\begin{tabular}{|c|}
$\begin{array}{c}\text { Standardize } \\
\text { Coefficient } \\
\text { s }\end{array}$ \\
\\
Beta \\
\end{tabular}} & \multirow[b]{2}{*}{$\mathrm{t}$} & \multirow[b]{2}{*}{ Sig. } & \multicolumn{2}{|c|}{$\begin{array}{l}\text { Collinearity } \\
\text { Statistics }\end{array}$} \\
\hline & B & Std. Error & & & & $\begin{array}{c}\text { Toleranc } \\
\mathrm{e}\end{array}$ & VIF \\
\hline $\begin{array}{l}1 \text { (Constan } \\
\text { t) }\end{array}$ & -3.728 & 3.816 & & .977 & .335 & & \\
\hline $\begin{array}{l}\text { SIAM } \\
(\mathrm{X} 1)\end{array}$ & .339 & .149 & .251 & $\begin{array}{r}2.27 \\
7\end{array}$ & .029 & .483 & 2.072 \\
\hline ST (X2) & .476 & .137 & .452 & $\begin{array}{r}3.46 \\
9\end{array}$ & .001 & .346 & 2.893 \\
\hline IN (X3) & .313 & .130 & .287 & $\begin{array}{r}2.40 \\
5\end{array}$ & .022 & .412 & 2.427 \\
\hline
\end{tabular}

a. Dependent Variable: KOP (Y) Sumber :

Data diolah oleh penulis, 2015

Dari hasil tabel

Coefficients diatas dapat terlihat

bahwa koefisien regresi untuk

variabel Sistem Informasi Akuntansi

Manajemen sebesar 0,339, untuk

variabel Strategi sebesar 0,476 ,

untuk variabel Inovasi sebesar

0,313, Selanjutnya persamaan regresi berganda dapat dirumuskan sebagai berikut :

$$
\begin{aligned}
& \mathrm{Y}=-3,728+0,339 \mathrm{SIAM}+0,476 \mathrm{ST} \\
& +0,313 \mathrm{IN}+\mathrm{e}
\end{aligned}
$$

Keterangan :

$\mathrm{Y}=$ Kinerja Operasional Perusahaan

(Y) 
SIAM $=$ Sistem Informasi Akuntansi

Manajemen (X1)

$\mathrm{ST}=$ Strategi $(\mathrm{X} 2)$

$\mathrm{IN}=\operatorname{Inovasi}(\mathrm{X} 3)$

e $\quad=$ Error

Berdasarkan Tabel 5, untuk

uji regresi berganda dapat

dijelaskan sebagai berikut :

a. Koefisien Sistem Informasi

Akuntansi Manajemen (X1) sebesar 0,339. Dilihat dari hasil uji regresi berganda pada Tabel

5, menunjukan bahwa setiap peningkatan 1 satuan variabel

Sistem Informasi Akuntansi

Manajemen akan meningkatkan

probabilitas Kinerja Operasional

Perusahaan. Begitu pula sebaliknya, jika variabel independen lain nilainya tetap dan nilai dari Sistem Informasi Akuntansi Manajemen mengalami penurunan 1 satuan, maka nilai dari variabel Kinerja Operasional Perusahaan akan Jurnal IImiah Wahana Akuntansi Volume 10, No.2, Tahun 2015 mengalami penurunan sebesar 0,339 satuan. Dalam hal ini pengaruh dari variabel independen $\quad \mathrm{X} 1 \quad$ adalah berbanding lurus dengan $\mathrm{Y}$. Artinya semakin meningkat $\mathrm{x} 1$, maka nilai Y juga akan semakin meningkat, begitu pula sebaliknya.

b. Koefisien Strategi (X2) sebesar 0.476. Dilihat dari hasil uji regresi berganda pada Tabel 5, menunjukkan bahwa setiap peningkatan 1 satuan variabel Strategi, maka akan meningkatkan probabilitas Kinerja Operasional Perusahaan. Begitu pula sebaliknya, jika variabel independen lain nilainya tetap dan nilai dari Strategi mengalami penurunan 1 satuan, maka nilai dari variabel Kinerja Operasional Perusahaan akan mengalami penurunan sebesar 0,476 satuan. 


\begin{tabular}{|c|c|}
\hline Dalam hal ini pengaruh dari & berbanding lurus dengan $\mathrm{Y}$. \\
\hline variabel independen $\mathrm{X} 2$ adalah & Artinya semakin meningkat $\mathrm{x} 3$, \\
\hline berbanding lurus dengan $\mathrm{Y}$. & maka nilai $\mathrm{Y}$ juga akan semakin \\
\hline Artinya semakin meningkat $\mathrm{x} 2$, & meningkat, \\
\hline maka nilai $\mathrm{Y}$ juga akan semakin & sebaliknya. \\
\hline meningkat, begitu pula & \\
\hline sebaliknya. & KESIMPULAN DAN SARAN \\
\hline Koefisien Inovasi (X3) sebesar & Berdasarkan hasil penelitian tersebut \\
\hline 0,313. Dilihat dari hasil uji & dapat disimpulkan bahwa: \\
\hline regresi berganda pada Tabel 5 , & Sistem informasi akuntansi \\
\hline menunjukkan bahwa setiap & manajemen berpengaruh positif \\
\hline peningkatan 1 satuan variabel & terhadap kinerja operasional \\
\hline Inovasi, maka akan & perusahaan. Hasil penelitian ini \\
\hline meningkatkan probabilitas & secara \\
\hline Operasional & membuktikan bahwa semakin baik \\
\hline Perusahaan. Begitu pula & sistem informasi akuntansi manajemen \\
\hline sebaliknya, jika variabel & di perusahaan maka akan \\
\hline independen lain nilainya tetap & meningkatkan probabilitas kinerja \\
\hline dan nilai dari Inovasi mengalami & operasional perusahaan. \\
\hline penurunan 1 satuan, maka nilai & Strategi berpengaruh positif \\
\hline dari variabel Kinerja Operasional & operasional \\
\hline Perusahaan akan mengalami & perusahaan. Hasil penelitian ini \\
\hline penurunan sebesar 0,313 satuan. & karena secara empiris membuktikan \\
\hline Dalam hal ini pengaruh dari & bahwa semakin baik strategi yang \\
\hline variabel independen X3 adalah & diterapkan oleh perusahaan, maka \\
\hline
\end{tabular}


akan meningkatkan probabilitas

kinerja operasional perusahaan.

Inovasi berpengaruh positif terhadap kinerja operasional perusahaan. Hasil penelitian ini karena secara empiris membuktikan bahwa semakin baik inovasi yang diimplementasikan oleh perusahaan, maka akan meningkatkan probabilitas kinerja operasional perusahaan.

Peneliti menyadari bahwa hasil penelitian yang telah dilakukan di atas masih banyak terdapat kekurangan dan keterbatasan yang belum sempurna. Untuk itu peneliti menyampaikan beberapa saran yang diharapkan dapat bermanfaat bagi berbagai pihak yang memiliki kepentingan dengan hasil penelitian, yaitu :

\section{Bagi Akademisi}

a. Pada penelitian ini sampel yang digunakan yaitu hanya orang yang bekerja di perusahaan Jurnal IImiah Wahana Akuntansi manufaktur wilayah DKI Jakarta, baik manajer operasional maupun staff operasional, sehingga hasil penelitian ini belum mewakili seluruh departemen yang ada di perusahaan manufaktur. Untuk peneliti selanjutnya disarankan untuk memperluas dengan menambahkan departemen yang ada di perusahaan manufaktur sebagai subjek penelitian, yaitu bagian Keuangan, Human Resource, dan lainnya.

b. Dalam penyebaran kuisioner, banyak kuisioner yang tidak diisi dengan lengkap oleh responden karena waktu penyebaran yang relatif singkat. Untuk peneliti selanjutnya diharapkan agar dapat menyebar kuisioner dalam jangka waktu yang relatif 
lebih panjang supaya responden

dapat menjawab dengan lebih

teliti.

c. Untuk penelitian lebih lanjut sebaiknya penggunaan variabel independen ditambah atau lebih variatif dengan mencakup aspek-aspek seperti Desentralisasi, Total Quality Management (TQM), Audit Operasional atau Etika Profesi Akuntansi.

\section{Bagi Perusahaan Manufaktur}

a. Agar dapat menerapkan sistem informasi akuntansi manajemen yang baik dengan cara mempekerjakan manajer yang handal dan ahli di bidangnya agar kinerja perusahaan dapat terorganisir dengan baik.

b. Seharusnya perusahaan menerapkan persaingan yang sehat terhadap produk kompetitor agar konsumenkonsumen yang baru dapat menilai sendiri produk yang berkualitas.

Agar perusahaan tidak selalu menjadi follower dan seharusnya menjadi trendsetter dalam melakukan inovasi. Selain itu perusahaan harus selalu upto-date terhadap kebutuhan konsumen 


\section{DAFTAR PUSTAKA}

Ahmad, Kamarudin. 2007. 2005. Evaluasi Kinerja. Akuntansi Manajemen. Bandung: Refika Aditama.

Jakarta: PT. Raja Grafindo Persada.

Manurung, Laurensius. 2010. Strategi dan Inovasi Model

Ancok, Djamaludin. 2012. Bisnis Meningkatkan Kinerja Kepemimpinan dan Inovasi. Jakarta : Erlangga. Dirgantoro, Crown. 2004. Manajemen Stratejik. Jakarta: PT. Grasindo. Fahmi, Irham. 2010. Manajemen Kinerja. Bandung: Alfabeta.

Ghozali, Imam. 2011. Aplikasi Analisis Multivariate Dengan Program SPSS. Semarang: BP Universitas Diponegoro.

Halwani, Hendra. 2005. Ekonomi Internasional dan Globalisasi Ekonomi. Bogor Selatan: Graha Indonesia.

Sugiyono. 2007. Metode Penelitian Pendidikan Pendekatan

Hansen \& Mowen. 2005. Management Accounting. Jakarta: Salemba Empat.

Kodrat, David Sukardi. 2009.

Manajemen Strategi. Yogyakarta: Graha Ilmu. Kuantitatif, Kualitatif, dan $R \& D$. Bandung: Alfabeta.

Mangkunegara, Anwar Prabu.

Sudarmanto. 2009. Kinerja dan Pengembangan Kompetensi. Yogyakarta: Pustaka Pelajar.

Kinerja. Jakarta: Lembaga
Penerbit Fakultas Ekonomi Universitas Indonesia.

Supratikno, Hendrawan. 2006. Manajemen Kinerja Untuk Menciptakan Keunggulan 
Bersaing. Yogyakarta: Graha Ilmu.

Tika, P. 2006. Budaya Organisasi dan Peningkatan Kinerja Perusahaan. Jakarta: PT. Bumi Aksara

Umar, Husein. 2010. Desain Penelitian Manajemen Strategik. Jakarta: Rajawali Pers. Wibowo. 2013. Manajemen Kinerja. Jakarta: Rajawali Pers 